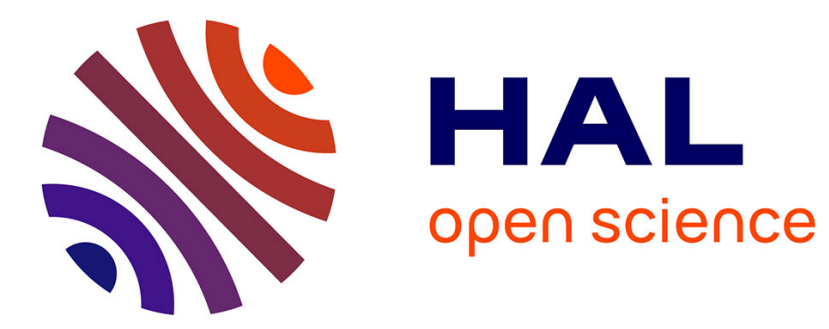

\title{
INTERNAL FRICTION TRANSIENT EFFECTS OF TITANIUM HYDROGEN SOLID SOLUTION
}

\author{
Y. Bertin, J. Gacougnolle, S. Sarrazin, J. de Fouquet
}

\section{To cite this version:}

Y. Bertin, J. Gacougnolle, S. Sarrazin, J. de Fouquet. INTERNAL FRICTION TRANSIENT EFFECTS OF TITANIUM HYDROGEN SOLID SOLUTION. Journal de Physique Colloques, 1981, 42 (C5), pp.C5-175-C5-180. 10.1051/jphyscol:1981527 . jpa-00221069

\section{HAL Id: jpa-00221069 https://hal.science/jpa-00221069}

Submitted on 1 Jan 1981

HAL is a multi-disciplinary open access archive for the deposit and dissemination of scientific research documents, whether they are published or not. The documents may come from teaching and research institutions in France or abroad, or from public or private research centers.
L'archive ouverte pluridisciplinaire HAL, est destinée au dépôt et à la diffusion de documents scientifiques de niveau recherche, publiés ou non, émanant des établissements d'enseignement et de recherche français ou étrangers, des laboratoires publics ou privés. 
JOURNAL DE PHYSIQUE

Colloque C5, supplément au no10, Tome 42 , octobre 1981

page $\mathrm{C} 5-175$

INTERNAL FRICTION TRANSIENT EFFECTS OF TITANIUM HYDROGEN SOLID SOLUTION

\begin{abstract}
Y.A. Bertin, J.L. Gacougnolle, S. Sarrazin and J. de Fouquet
Ecole Nationale Supérieure de Mécanique et d'Aérotechnique, Laboratoire de Mécanique et de Physique des Matériaux, Equipe de Recherche Associée au C.N.R.S. 86034 Poitiers Cedex, France
\end{abstract}

Abstract. - The internal friction of pure Ti between $500 \mathrm{~K}$ and $700 \mathrm{~K}$ is constant at $10^{-4}$ when measured during a continuous increase of temperature. In opposite when the temperature is increased step by step, each increase of $10 \mathrm{~K}$ induces immediatly a raising up of $41^{-4}$ internal friction. During the following stage at the new temperature the internal friction falls slowly down to its initial value.

This behaviour can be attributed to either the sudden modification of the thermodynamic equilibrium of pure titanium or the presence of a small amount of hydrogen trapped by the specimen during the experiment. This paper compares the internal friction of pure titanium and titanium containing $7 \mathrm{w} . \mathrm{ppm}$ of hydrogen.

- $i$ - the internal friction background is increased from $10^{-4}$ up to $3010^{-4}$.

- ii - the transient maximum of internal friction due to the temperature steps is 10 times as high as the corresponding value obtained with pure titanium.

- iii - at temperatures higher than 700K large instabilities both of damping and modulus are recorded and it is not possible to reach an equilibrium value.

It can be concluded that the transient maximums of internal friction are specific of the metal, the presence of hydrogen increases the amplitude of the effects.

Introduction. - The spectrum of damping of titanium at $1 \mathrm{~Hz}$ is determined by increasing the temperature, step by step, from $200^{\circ} \mathrm{C}$ to $475^{\circ} \mathrm{C}(1)$. Each step gives rise to a sudden increase of the damping, and once the temperature is stabilized, the internal friction decreases slowly to reach its equilibrium value for this temperature. The maximum value of the transient internal friction, is twice the equilibrium value for a change of temperature of $10^{\circ} \mathrm{C}$. This transient effect is observed for an increase or a decrease of the temperature greater than $5^{\circ} \mathrm{C}$.

This transient effect has been observed on high purity titanium, hence it is difficult to attribute it to chemical instabilities; nevertheless its very low activation energy $(0.2 \mathrm{eV})$ could indicate the contribution of hydrogen to this process. Hydrogen could come from a superficial chemical reaction between titanium and residual oil vapour in vacuum during the heat treatment which follows the mounting of the 
specimen of pure titanium on the pendulum. In order to verify this hypothesis the transient effects on pure titanium and $\mathrm{T} i$ containing 0.15 at. $\% \mathrm{H}$ are compared.

Experimental procedure.- The specimens are platelets (80x8xl mm) of high purity titanium with major impurities (at.ppm): 0,$20 ; \mathrm{N}, 20$; $\mathrm{C}, 6 ; \mathrm{Fe}, 2$; Mn ; Mg ; Si<1. The high degree of purity is confirmed by the very low elastic limit : $40 \mathrm{MPa}$. Hydrogen is added to titanium by electrolysis in $\mathrm{H}_{2} \mathrm{SO}_{4}$ (4N) with a current density of $20 \mathrm{~mA} / \mathrm{cm}^{2}$ for $1 \mathrm{~mm}$.

The internal friction is measured in an inverted torsion pendulum by the free decay method at a frequency of about $1 \mathrm{~Hz}$. The maximum amplitude is $5 \times 10^{-6}$ and the accuracy of measurement of damping $\Delta Q^{-1}$ is $\pm 10^{-5}$. The temperature is maintained constant within $\pm 0.25^{\circ} \mathrm{C}$ as long as necessary.

After mounting on the pendulum, the specimens of pure titanium are annealed at $800^{\circ} \mathrm{C}$ for 1 hour in vacuum of $5 \times 10^{-6}$ torr. The specimens of $\mathrm{Ti}-0.15$ at $\% \mathrm{H}$ do not receive this heat treatment to avoid the loss of hydrogen in vacuum (2) as three specimens heat treated at $800^{\circ} \mathrm{C}$ in ultra-vacuum behave like pure titanium.

Transient effects of pure titanium.- The transient of damping is shown on figure 1 .

After several hours at $359^{\circ} \mathrm{C}$ the specimen exhibits a nearly stable damping : $\mathrm{Q}^{-1}=2 \times 10^{-4}$. The temperature is then brought to $370^{\circ} \mathrm{C}$, this change of temperature takes one hour. In the figure 1 it can be checked that the period of the pendulum increases simultaneously with the temperature indicated by the thermocouple.

As soon as the temperature of the specimen increases its internal friction rises. The maximum value $\mathrm{Q}_{\mathrm{M}}^{-1}=4.2 \times 10^{-4}$ is reached $20 \mathrm{mn}$ after the start of the heating and then the damping decreases exponentialy. The equilibrium value $Q_{\infty}^{-1}=2 \times 10^{-4}$ is reached after 6 hours following the relationship (fig. 2) :

$$
Q^{-1}(t)=Q_{\infty}^{-1}+\left(Q_{M}^{-1}-Q_{\infty}^{-1}\right) \exp -\frac{t}{\tau^{*}}|1|
$$

The transient effect is defined by 2 parameters : its magnitude $\left(Q_{M}^{-1}-Q_{\infty}^{-1}\right)$ and its decreasing rate related to the characteristic time

As shown in figures 3 and 4 these two parameters are functions of the temperature: the value $\left(Q_{M}^{-1}-Q_{\infty}^{-1}\right)$ increases slowly from $1 \times 10^{-4}$ at $230^{\circ} \mathrm{C}$ to $3.5 \times 10^{-4}$ at $437^{\circ} \mathrm{C}$, then decreases rapidly and the transient 
effect vanishes at $470^{\circ} \mathrm{C}$. The characteristic time first decreases from $5 \mathrm{~h}$ at $230^{\circ} \mathrm{C}$ to $2.5 \mathrm{~h}$ at $430^{\circ} \mathrm{C}$, and it rises suddenly up to $5.5 \mathrm{~h}$ at $437^{\circ} \mathrm{C}$ then decreases again to $1 \mathrm{~h}$ at $465^{\circ} \mathrm{C}$. So two temperature ranges must be distinguined : one below $430^{\circ} \mathrm{C}$ with an activation energy of $0.2 \mathrm{eV}$ and another above $430^{\circ} \mathrm{C}$ with an activation energy $2.6 \mathrm{ev}$.

The transient effect is influenced by several parameters : the purity of titanium, the content of oxygen, the microstructure and also the conditions of the temperature changes. All the parameters will be considered in detail in a future article (7). In this paper we study the influence of hydrogen only.

Transients effects of Ti-0.15 at $\mathrm{H}$. - Measurements habe been made raising the temperature step by step from $20^{\circ} \mathrm{C}$ up to $450^{\circ} \mathrm{C}$ this temperature range was covered twice on each sample. During the first heating the specimen behaves like the pure material but the values of $Q_{M}^{-1}$ and $Q_{\infty}^{-1}$ are increased by a factor 2. In the figure 5 the values of $Q_{M}^{-1}$ and $Q_{\infty}^{-1}$ are respectively $12.5 \times 10^{-4}$ and $4 \times 10^{-4}$ at $355^{\circ} \mathrm{C}$ instead of $4.2 \times 10^{-4}$ and $2 \times 10^{-4}$ for the pure metal. The sample is held for 6 hours at $400^{\circ} \mathrm{C}$ and then cooled on the pendulum.

During the second heating the transient maximum and the equilibrium value are increased : at $365^{\circ} \mathrm{C}$ the values of $\mathrm{Q}_{\mathrm{M}}^{-1}$ and $\mathrm{Q}_{\infty}^{-1}$ are $95 \times 10^{-4}$ and $35 \times 10^{-4}, 20$ times their values on the pure metal, but the characteristic time $\tau^{*}=2 \mathrm{~h}$ remains identical (fig. 6). The maximum of the transient is reached $80 \mathrm{mn}$ after the beginning of the change of the temperature, so the damping continues to increase for $30 \mathrm{mn}$ after the temperature is stabilized.

Above $420^{\circ} \mathrm{C}$ a new kind of instability appears during the holds at constant temperatures; three examples are given below: i) At $432^{\circ} \mathrm{C}$ (fig $7 \mathrm{a}-7 \mathrm{~b}$ ) the decrease of $Q^{-1}$ which follows the maximum is scattered, $\Delta Q^{-1}= \pm 10 \times 10^{-4}$, compared to the scattering at $365^{\circ} \mathrm{C}$ which is only $\pm 2 \times 10^{-4}$. Moreover after 4 hours at $432^{\circ} \mathrm{C}$ the damping raises suddenly from 100 to $200 \times 100^{-4}$ whereas the nodulus remains constant. During the first 4 hours the period decreases simultaneously with the damping but the amplitude effect is inversed after 2 hours. ii) During the hold at $462^{\circ} \mathrm{C}$ (fig. $8 \mathrm{a}-8 \mathrm{~b}$ ) it was not possible to analyze the variations of the damping. We could only observed that $\mathrm{Q}^{-1}<100 \times 10^{-4}$. The period measurements are also scattered. They vary from 4.5 to $4.85 \mathrm{~s}$, which corresponds to a modulus defect 
$\frac{\Delta G}{G}=15 \times 10^{-2}$. This high modulus defect cannot be directly related to the damping.

iii) At $471^{\circ} \mathrm{C}$ (fig. $9 \mathrm{a}-9 \mathrm{~b}$ ) the simultaneous variations of the damping and the period occur every $90 \mathrm{mn}$ after the first maximum but these variations are in contradiction : after 3 hours at $471^{\circ} \mathrm{C}, Q^{-1}$ decreases from 60 to $40 \times 10^{-4}$ whereas the increase of the period shows a modulus decrease of $180 \times 10^{-4}$ instead of a modulus increase.

Discussion. - The solubility of hydrogen in titanium is approximately 0.1 at $\%$ at $20^{\circ} \mathrm{C}$ and 10 at $\%$ at $300^{\circ} \mathrm{C}$ (3) (4) (5), but the original Ti-H diagram, given by lenning et al, is not established between $350^{\circ} \mathrm{C}$ and $600^{\circ} \mathrm{C}$.

When the hydrogen ions go into the specimen they precipitate close to the surface because of the low solubility of hydrogen at room temperature. These hydrides are dissolved during the first heating at $400^{\circ} \mathrm{C}$, then hydrogen is entirely in solid solution for temperatures higher than $200^{\circ} \mathrm{C}$.

The transient phenomenons in pure titanium are attributed to the modifications of the equilibrium position of the dislocations in the Frank network as this equilibrium network is different for different temperatures. Some dislocations are temporarily unpinned and can contribute to the damping until they are pinned again.

The two temperature ranges below and above $430^{\circ} \mathrm{C}$ which are described for pure titanium exist also for the titanium-hydrogen solid solution. Below $400^{\circ} \mathrm{C}$ the presence of hydrogen magnifies the transient effects, increases the equilibrium values $Q_{\infty}^{-1}$ and delays the time necessary to reach $Q_{M}^{-1}$ after the temperature change but the characteristic time $\tau^{*}$ is not modified. The interaction of unpinned dislocations with the numexous isolated hydrogen atoms contributes certainly in the increase of the damping as suggested by Richtie et al.

For temperatures higher than $400^{\circ} \mathrm{C}$, the sudden and opposite variations of the damping and the modulus during the holds at constant temperature can be explained only by chemical instabilities. Bertin has shown that the vacancies are mobile at temperatures higher than $420^{\circ} \mathrm{C}$ and that the diffusion of vacancies is the controling process of the characteristic time $\tau^{*}$ in pure titanium for this temperature range. In the case of the titanium-hydrogen solid solution the variations of $Q^{-1}$ are so high that the characteristic time has no signification. C.W. Schoenfelder et al (2) have shown that hydrogen leaves titanium in vacuum for temperatures higher than $400^{\circ} \mathrm{C}$ by a process 
of diffusion through a gaseous boundary layer on the surface of the specimen but they do not give any information on the nature of this layer. The action of this layer on the damping and the modulus of the specimen would be a good way of investigation.

(1) Y.A. Bertin Thesis - Poitiers 1979.

(2) C.W. Schoenfelder and J.H. Swisher J. Vac. Sci. Tech. 10, vol. 5, 1973, 862.

(3) G.A. Lenning, C.M. Craighead and R.J. Jaffee Trans. ATME 200, 1954, 367.

(4) R.S. Vitt and Kanji Ono Metall. Trans, 608, vol. 2, 1971, 608.

(5) W. Köster, L. Bangert and M. Evers Z. Metallkunde 17, 1956, 564.

(6) I.G. Richtie, A. Atrens and D.G. Blair Private communication.

(7) Y.A. Bertin, J.I. Gacougnolle and D. Beshers to be published.

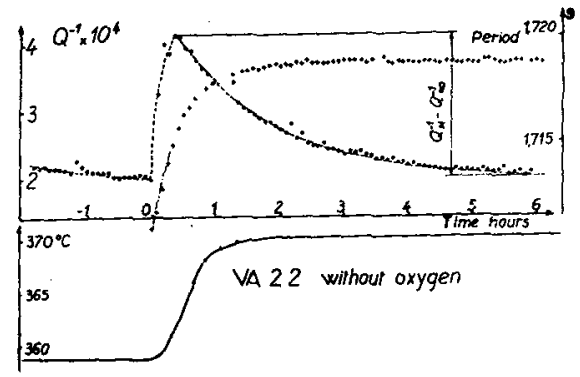

Fig. 1 : Variation of period and internal friction of pure titanium due to an increase of the temeprature.

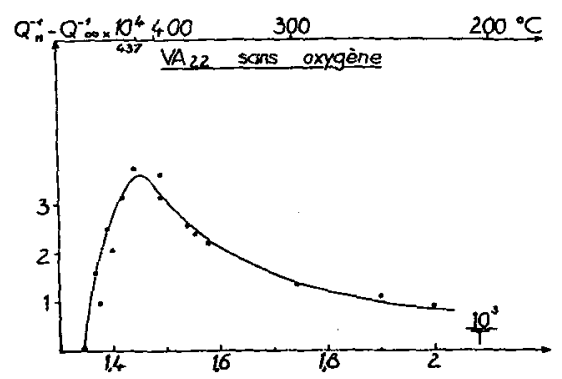

$\begin{aligned} \text { Fig. } 3 \text { : Variation of } & \left(Q_{M}^{-1}-Q_{\infty}^{-2}\right) \text { with the } \\ \text { temperature. } & \end{aligned}$

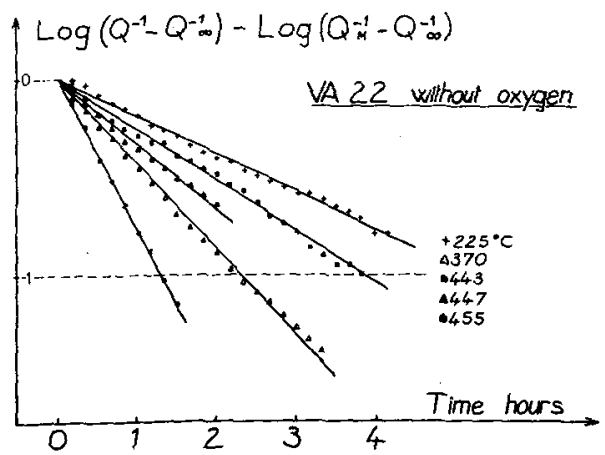

Fig. 2 : Verification of the relationship |1| for different temperatures.

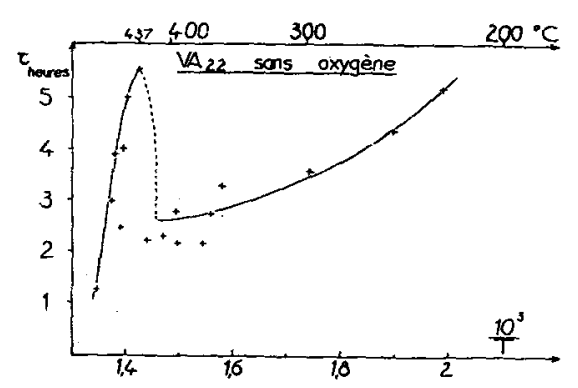

Fig. 4 : Variation of $\tau^{*}$ with the tempera- 


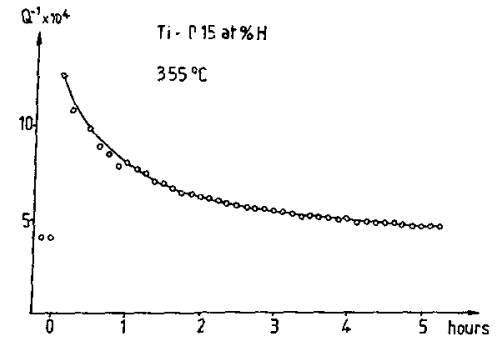

Fig. 5 : Transient effect of $\mathrm{Ti}-0.15$ at $\mathrm{H}$ at $355^{\circ} \mathrm{C}$ during the fixst heating.

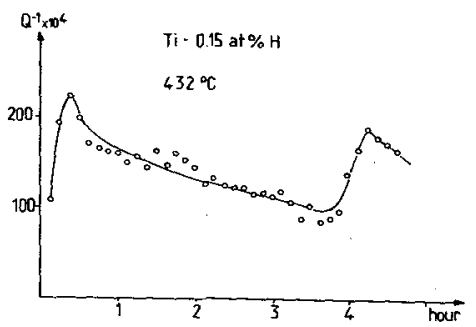

Fig. $7 \dot{a}=$ Internal friction of $\mathrm{Tj}-0.15$ at $8 \mathrm{H}$ at $432^{\circ} \mathrm{C}$.

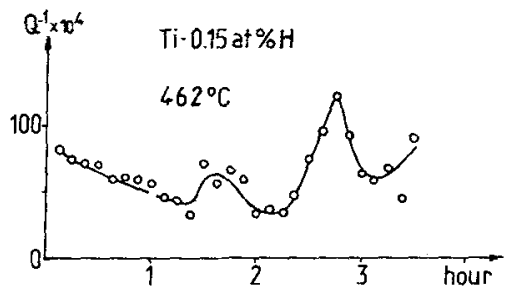

Fig. $8 \mathrm{a}$ : Internal friction of Ti-0.15 at $H$ at $462^{\circ} \mathrm{C}$

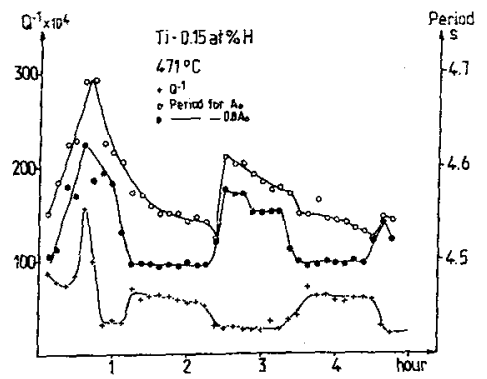

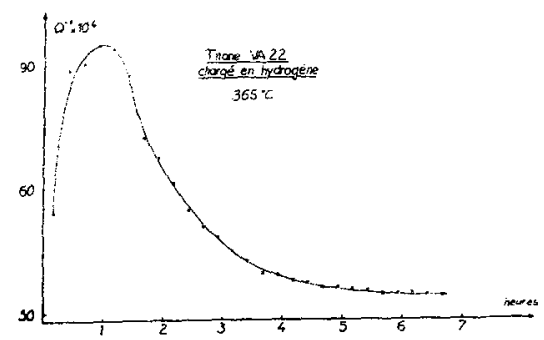

Fig. 6 : Transient effect of Ti-0.15 at of $\mathrm{H}$ at $365^{\circ}$ during the second heating.

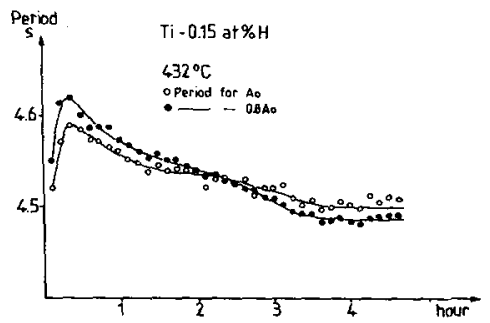

Fig. $7 \mathrm{~b}$ : Pexiod of $\mathrm{Ti}-0.15$ at $\mathrm{H}$ at $432^{\circ} \mathrm{C}$.

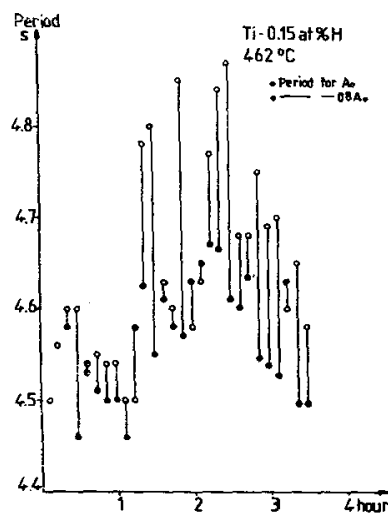

Fig. 8b : Period of Ti-0.15 at \& H at $462^{\circ} \mathrm{C}$. 